\title{
Taxonomic Implications of the Lipid Composition of Pseudomonas pertucinogena
}

\author{
YOKO KAWAI AND ATSUKO F. MORIBAYASHI \\ Department of Bacteriology I and Department of Technology, National Institute of Health, Shinagawa-ku, \\ Tokyo 141, Japan
}

\begin{abstract}
The neutral solvent-extractable lipids and the residual bound lipids of Pseudomonas pertucinogena were analyzed. The major components of the extractable lipid fraction were phosphatidylethanolamine, cardiolipin, phosphatidylglycerol, and lysocardiolipin. The high cardiolipin content was a characteristic feature. Various fatty acids were detected in the extractable lipids, the major acids being hexadecanoic and octadecenoic. The fatty acid compositions of individual phos. pholipids were also determined. The fatty acids of the bound lipids, which differed distinctly from those of the extractable lipids, were mainly $(80 \%) 3$-hydroxy acids (3-hydroxydecanoic acid, 3-hydroxyundecanoic acid, 3-hydroxyisoundecanoic acid, 3-hydroxydodecanoic acid, and 3-hydroxypentadecanoic acid); the remainder $(20 \%)$ were saturated fatty acids including dodecanoic acid and tridecanoic acid. The amino sugar in lipid $A$, which was the lipid fraction of the lipopolysaccharide, was identified as glucosamine. The present findings provide additional support for the recognition of $P$. pertucinogena as a distinct species of the genus Pseudomonas, even though the strains placed in this species had long been accepted as members of Bordetella pertussis and produce a bacteriocin active against phase I strains of $B$. pertussis.
\end{abstract}

Until 1974 (7), American Type Culture Collection (ATCC) strains 190 and 6627 were labeled as rough phase IV strains of Bordetella pertussis. During a study of the bacteriocin produced by these two strains and active against phase I strains of $B$. pertussis (9), Kawai (7) noticed that these bacteriocin-producing strains were more like pseudomonads than bordetellas in their morphological and biochemical attributes. This view was substantiated by studies by Kawai of the guanine-plus-cytosine contents of the deoxyribonucleic acids and of the DNA homology of the strains. Since these bacteriocin-producing strains were not identified as belonging to any of the then-known Pseudomonas species, a new name, Pseudomonas pertucinogena, was proposed for them in 1975 by Kawai and Yabuuchi (8).

The present paper reports on the lipid composition of these organisms and on the taxonomic implications thereof.

\section{MATERIALS AND METHODS}

Bacterial strains. Cultures of strains ATCC 190 and ATCC 6627, which are now regarded as members of $P$. pertucinogena, were obtained from the American Type Culture Collection. ATCC 190 is the type strain of $P$. pertucinogena.

Cell preparation. The organisms were precultured on slants of Bordet-Gengou medium at $37^{\circ} \mathrm{C}$ and transferred to Cohen-Wheeler medium slants for growth at $37^{\circ} \mathrm{C}$ for $45 \mathrm{~h}$. The cells were harvested and suspended in $0.9 \%$ sodium chloride solution; the suspension was filtered through six sheets of gauze, and the cells were washed four times with $0.9 \%$ sodium chloride solution. From a $500-\mathrm{ml}$ culture, $0.28 \mathrm{~g}$ (dry weight) of cells was obtained. For the identification and quantitative analysis of phospholipids, the organisms were cultured in Jebb and Tomlinson medium (5) containing $\left[{ }^{3} \mathrm{H}\right]$ glycerol or $\left[{ }^{14} \mathrm{C}\right]$ sodium acetate at $37^{\circ} \mathrm{C}$ for 18 or $48 \mathrm{~h}$.

Extraction of lipids. Lipids were extracted by the method of Bligh and Dyer (2). One gram of cells washed as above was homogenized by stirring for 30 min with $20 \mathrm{ml}$ of $0.9 \%$ sodium chloride, $50 \mathrm{ml}$ of methanol, and $25 \mathrm{ml}$ of chloroform. To the mixture was added another $25 \mathrm{ml}$ of chloroform. The mixture was stirred overnight, after which $25 \mathrm{ml}$ of $0.9 \%$ sodium chloride solution was added and stirring was continued for $10 \mathrm{~min}$. The chloroform layer (the lower phase) was separated and evaporated. The lipid extract was dissolved in chloroform-methanol $(2: 1, \mathrm{vol} / \mathrm{vol})$, and the solution was then passed through a glass filter to remove insoluble materials. The filtrate was evaporated again to give "extractable lipids."

The bacterial residue was stirred overnight in chloroform-methanol $(2: 1, \mathrm{vol} / \mathrm{vol})$ and was then washed thoroughly with the same solvent. The lipids contained in the residual fraction were regarded as "bound lipids."

Analysis and fractionation of the extracted lipids. The lipids extracted were analyzed by thinlayer chromatography (TLC) on Merck $F_{254}$ silica gel plates. Neutral lipids and phospholipids were separated by development with petroleum ether-etheracetic acid (80:30:1 or 90:10:1, vol/vol). The phospho- 
lipids were developed with two solvent systems: chloroform-methanol-water $(65: 25: 4$, vol/vol) and chloroform-methanol-acetic acid (65:25:10, vol/vol). Lipids were located either by spraying with Dittmer reagent or by charring with $50 \%$ sulfuric acid. For preparative purposes, lipids were detected with iodine vapor. The spots were then scraped off and extracted with chloroform-methanol $(2: 1, \mathrm{vol} / \mathrm{vol})$.

Deacylation of phospholipids. Deacylation of phospholipids was performed by mild alkaline hydrolysis by the method of Dawson (3). The degradation products were separated by paper chromatography on filter paper (Toyo no. 50) with phenol-water-acetic acid-ethanol $(80: 20: 10: 12$, vol/vol) or isopropanol-ammonia-water $(7: 2: 1, \mathrm{vol} / \mathrm{vol})$ as the solvent system.

Analysis of fatty acids. Separation of fatty acids as methyl esters from the extractable (EL) and bound lipids (BL) was carried out by methanolysis with $5 \%$ hydrochloric acid-methanol in a sealed tube at $110^{\circ} \mathrm{C}$ for $3 \mathrm{~h}$ for $\mathrm{EL}$ and $5 \mathrm{~h}$ for $\mathrm{BL}$ and by subsequent extraction with hexane and $2 \%$ potassium bicarbonate. Fatty acids were also separated from the EL and BL by alkaline hydrolysis with a mixture of $4.2 \mathrm{ml}$ of $85 \%$ potassium hydroxide, $15 \mathrm{ml}$ of methanol, and $15 \mathrm{ml}$ of water at $85^{\circ} \mathrm{C}$ for $30 \mathrm{~min}$. The hydrolyzed material was washed with petroleum ether and then extracted three times each with $25 \mathrm{ml}$ of ether after acidification with hydrochloric acid. The extracts were combined, washed with $2 \%$ potassium chloride, and evaporated to dryness. Fatty acids thus obtained were then methylated with diazomethane. To verify monoenoic acids, their methyl esters from EL were separated from methyl esters of saturated acids by means of TLC with a solvent system of hexane-ether $(95: 5, \mathrm{vol} / \mathrm{vol})$ on a plate sprayed with $30 \%$ silver nitrate solution. To analyze EL and BL for hydroxy fatty acid, fatty acid methyl esters were developed on a TLC plate with a solvent system of petroleum ether-ether-acetic acid $(80: 30: 1$, vol/vol). Since BL was found to contain hydroxy fatty acids, the mixture of methyl esters was then fractionated on a TLC plate with a solvent system of petroleum ether-ether $(1: 1, \mathrm{vol} / \mathrm{vol})$ for gas-liquid chromatography. This procedure was necessary because some hydroxy fatty acids have the same retention times as nonhydroxy fatty acids. Each spot was scraped off and extracted with chloroform-methanol (2:1, vol/vol). Fatty acid methyl esters thus separated were subjected to gas-liquid chromatography. Fatty acids in the sample were identified by comparing the retention times of the esterified acids with those of the standards. EL of Escherichia coli K-12, soybean oil, $\mathrm{EL}$ and $\mathrm{BL}$ of Flavobacterium meningosepticum strains KM 505 and 1204 (22), Pseudomonas stutzeri strain KM 401, and Pseudomonas aeruginosa strain KM 255 (23) (KM: strain number of Kansai Medical School) and BC-MIX-L (Applied Science) were used as fatty acid references. 2-Hydroxydodecanoic, 2-hydroxytetradecanoic, 3-hydroxydecanoic, 3-hydroxytetradecanoic, and heptadecanoic acids were also used as references. Gas-liquid chromatography was carried out with a Shimazu type GC-1C apparatus with a hydrogen flame ionization detector. The stainless-steel column, $2 \mathrm{~m}$ in length, was packed with $15 \%$ diethylene glycol succinate or $2.5 \% \mathrm{SE}-30$ on chromosorb $\mathrm{W}$. The column temperature was either 150 or $170^{\circ} \mathrm{C}$. Hydroxy fatty acids were further verified by mass spectrometry with a TMS-D 100 gas chromatograph-mass spectrometer (Nihon Denshi Co.) with a column of 3\% OV-17 ( $2 \mathrm{~m}$ by $3 \mathrm{~mm}$ ). The energy of the bombarding electrons was $30 \mathrm{eV}$, and the temperature of the ion source was $200^{\circ} \mathrm{C}$.

Analysis of lipid A for amino sugar. Lipopolysaccharide was prepared by the phenol-water method of Westphal and Jann (19) from the organisms defatted by the Bligh and Dyer method and washed thoroughly with chloroform-methanol (2:1, vol/vol). Ribonuclease, instead of cetavlon, was used to remove ribonucleic acid. The lipopolysaccharide fraction was cleaved with $1 \%$ acetic acid at $100^{\circ} \mathrm{C}$ for $1 \mathrm{~h}$. Lipid A was extracted by vigorous mixing with an equal volume of chloroform. The chloroform layer of the mixture obtained by low-speed centrifugation was isolated, washed with water, and dried to give lipid A. After hydrolysis of lipid A with $6 \mathrm{~N} \mathrm{HCl}$ at $110^{\circ} \mathrm{C}$ for $4 \mathrm{~h}$, amino sugar was separated by two-dimensional paper electrophoresis with a solvent system of pyridine-acetic acid-water (60:1.8:940, vol/vol; $\mathrm{pH} 6.7$ ), at $50 \mathrm{~V} / \mathrm{cm}$ for $40 \mathrm{~min}$ followed by chromatography with a solvent mixture of ethyl acetate-pyridine-wateracetic acid (5:5:3:1, vol/vol).

Chemicals. All chemicals employed were of the highest purity available commercially. Chloroform was redistilled before use. Reference fatty acids were kindly supplied by I. Yano (Osaka City University, Osaka, Japan) and Y. Akamatsu (National Institute of Health, Tokyo, Japan).

\section{RESULTS}

General analysis of the extractable lipids. A 91-mg amount of EL was obtained from $1 \mathrm{~g}$ (dry weight) of cells. When the total ELs were chromatographed on a thin-layer plate with chloroform-methanol-acetic acid (65:25:10, $\mathrm{vol} / \mathrm{vol}$ ), at least three main spots were located by charring with $50 \%$ sulfuric acid. They were estimated to be cardiolipin, phosphatidylglycerol, and phosphatidylethanolamine by comparison of their $R_{f}$ values with those of authentic standards. When two-dimensional TLC, first developed with chloroform-methanol-water $(65: 25: 4, \mathrm{vol} / \mathrm{vol})$ in the vertical direction and secondly with chloroform-methanol-acetic acid $(65: 25: 10, \mathrm{vol} / \mathrm{vol})$ in the horizontal direction, was applied to EL, a spot of unknown phospholipid was separated in addition to the three mentioned above (Fig. 1). The spots were located by spraying with the Dittmer reagent or by charring with sulfuric acid, but only the phosphatidylethanolamine spot developed color with the ninhydrin reagent.

To determine the distribution of individual phospholipids and to identify the unknown phospholipid, further analysis was conducted. A sample of EL was obtained from the organisms grown in the medium containing $\left[{ }^{3} \mathrm{H}\right]$ glycerol or $\left[{ }^{14} \mathrm{C}\right]$ sodium acetate and was subjected to twodimensional TLC. Spots were located with iodine vapor and were scraped off for counting of 

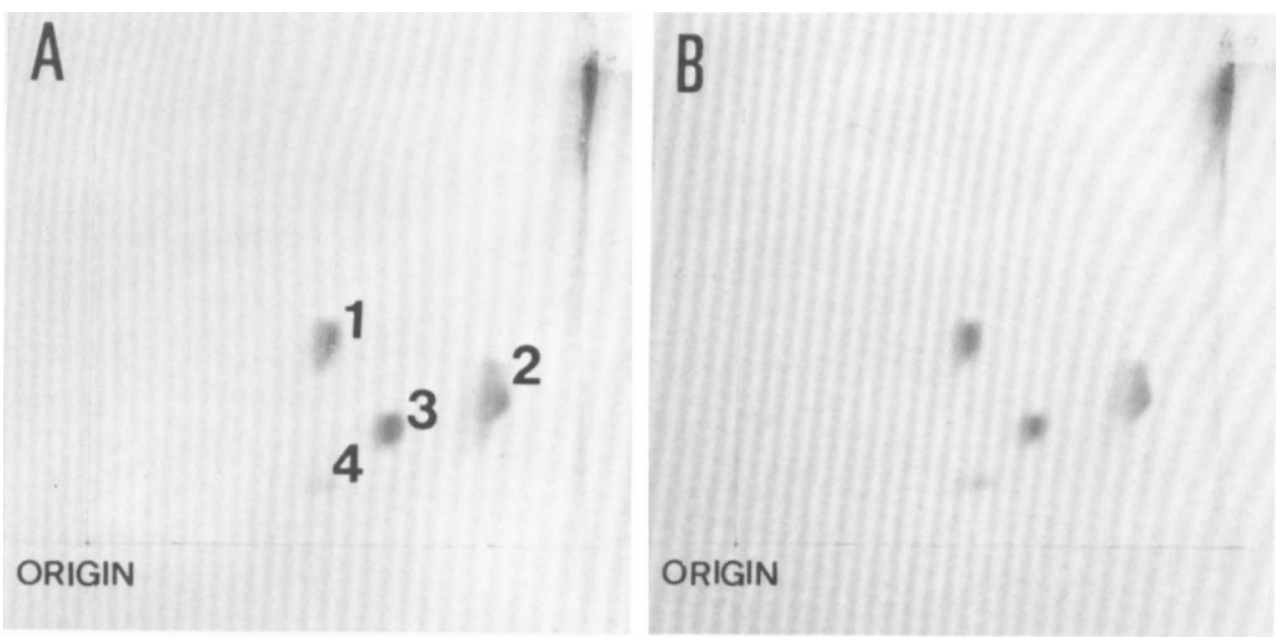

FIG. 1. Two-dimensional thin-layer chromatograms of extractable lipids of P. pertucinogena ATCC 190 and ATCC 6627. Solvent systems used were: first, chloroform-methanol-water (65:25:4) in the vertical direction, and second, chloroform-methanol-acetic acid (65:25:10) in the horizontal direction. The plate was charred with 50\% sulfuric acid. (A) ATCC 190; (B) ATCC 6627. (1) Phosphatidylethanolamine; (2) cardiolipin; (3) phosphatidylglycerol; (4) unknown phospholipid.

radioactivity, from which the percent distribution of each phospholipid was calculated. The ${ }^{3} \mathrm{H}$-labeled gel was extracted with chloroformmethanol (2:1, vol/vol) and was hydrolyzed mildly by the method of Dawson (3). The degradation products were then subjected to paper chromatography as described before. The $R_{f}$ values of the $\left[{ }^{3} \mathrm{H}\right]$ glycerol-containing phosphorus compounds were determined from the scanning patterns of radioactivity (Fig. 2).

From the results of these analyses and from the pattern of the two-dimensional TLC shown in Fig. 1, the unknown phospholipid was considered to be lysocardiolipin. As stated later, the fatty acid pattern of this phospholipid gave further support to this assumption. The presence of cardiolipin, phosphatidylethanolamine, and phosphatidylglycerol were confirmed in the degradation study, in which the Dawson method (3) was used. Phosphatidylethanolamine and cardiolipin accounted for more than $80 \%$ of the total phospholipid in both ATCC 190 and 6627 regardless of their growth phase (Table 1).

Fatty acid composition of the extractable and bound lipids. The yield of BL was about one-tenth that of EL. TLC of fatty acid methyl esters revealed that most of the fatty acids of EL were of the nonhydroxy type, and those of $\mathrm{BL}$ were of the 3-hydroxy type (Fig. 3). The spots seen at the top of this figure did not appear when extraction was made with hexane instead of ether. In TLC with petroleum ether-etheracetic acid (80:30:1 or 90:10:1, vol/vol), few free fatty acids were detected in EL.
TABLE 1. Phospholipid composition of $P$. pertucinogena ATCC 190 and ATCC 6627 in the exponential and stationary phases of growth

\begin{tabular}{|c|c|c|c|c|}
\hline \multirow{3}{*}{ Phospholipid } & \multicolumn{4}{|c|}{$\begin{array}{l}\text { Amt of phospholipid (mol\% of total phospho- } \\
\text { rus) }{ }^{a} \text { present in: }\end{array}$} \\
\hline & \multicolumn{2}{|c|}{ Cells of ATCC 190} & \multicolumn{2}{|c|}{ Cells of ATCC 6627} \\
\hline & $\begin{array}{l}\text { During } \\
\text { exponen- } \\
\text { tial phase } \\
\text { of growth }\end{array}$ & $\begin{array}{c}\text { During } \\
\text { stationary } \\
\text { phase of } \\
\text { growth }\end{array}$ & $\begin{array}{l}\text { During } \\
\text { exponen- } \\
\text { tial phase } \\
\text { of growth }\end{array}$ & $\begin{array}{l}\text { During } \\
\text { stationary } \\
\text { phase of } \\
\text { growth }\end{array}$ \\
\hline $\begin{array}{l}\text { Phosphati- } \\
\text { dyleth- } \\
\text { anolam- } \\
\text { ine }\end{array}$ & 47 & 43 & 45 & 42 \\
\hline Cardiolipin & 36 & 41 & 34 & 42 \\
\hline $\begin{array}{l}\text { Phosphati- } \\
\text { dylglycerol }\end{array}$ & 10 & 9 & 12 & 9 \\
\hline $\begin{array}{l}\text { Lysocardioli- } \\
\text { pin }\end{array}$ & 7 & 7 & 9 & 8 \\
\hline
\end{tabular}

${ }^{a}$ Calculated from the radioactivity of $\left[{ }^{3} \mathrm{H}\right]$ glycerol or $\left[{ }^{14} \mathrm{C}\right]$ sodium acetate in phospholipids extracted from a two-dimensional thin-layer plate.

The fatty acid composition of EL is shown in Table 2. Major fatty acids were hexadecanoic acid and octadecenoic acid; other fatty acids of various carbon number, including odd-numbered ones, were detected. In this respect, the two strains were similar to each other but differed in the heptadecenoic acid content. A small quantity of 2-hydroxytetradecanoic acid was detected. Each phospholipid was also analyzed for the fatty acid composition. The fatty acid composition of phosphatidylethanolamine and that 
A
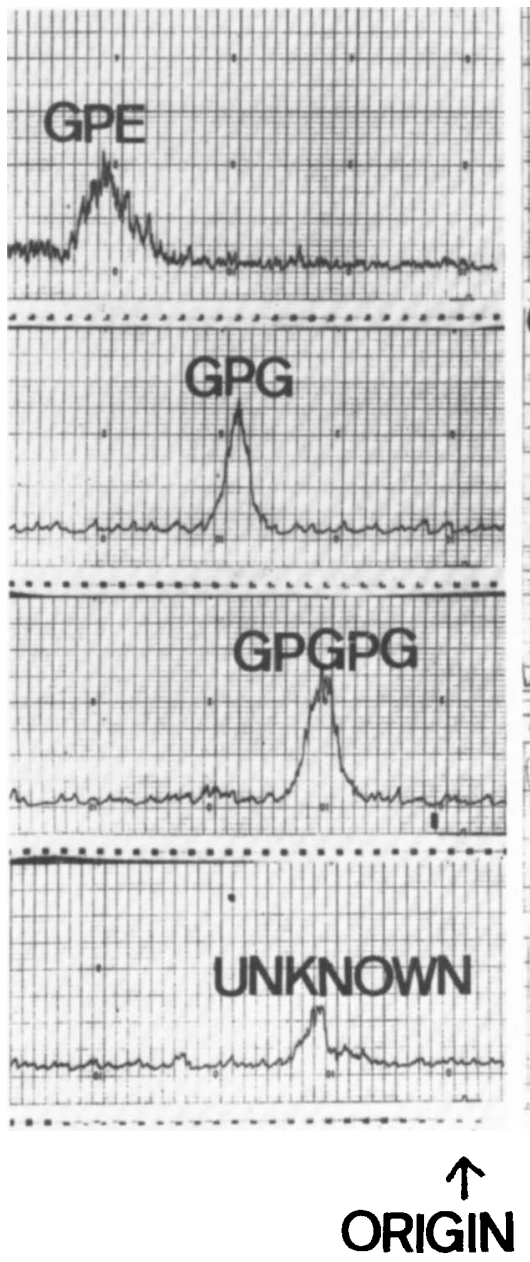

B
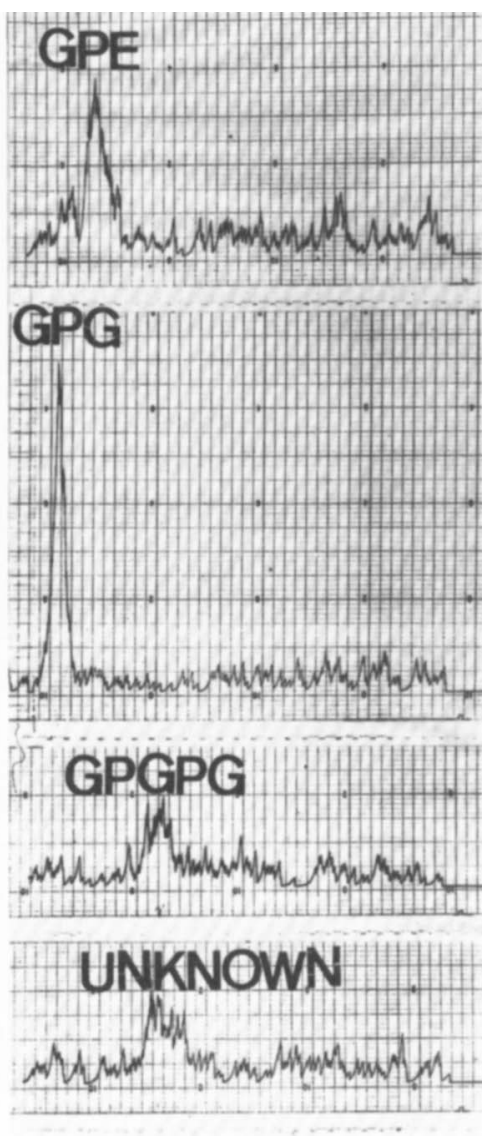

FIG. 2. Scanning pattern of paper chromatograms of $\left[{ }^{3} \mathrm{H}\right]$ glycerylphosphoryl derivatives obtained by mild alkaline hydrolysis by the method of Dawson (3). Solvent systems used were (A) phenol-water-acetic acidethanol (80:20:10:12) and (B) isopropanol-ammonia-water (7:2:1).

of cardiolipin were similar to each other and to that of the total EL. The fatty acid composition of phosphatidylglycerol was slightly different from that of phosphatidylethanolamine with respect to octadecenoic acid and tetradecenoic acid.

The fatty acid composition of lysocardiolipin was highly characteristic with respect to its hexadecanoic acid $(60 \%)$ and tetradecenoic acid (10\%) content. Such a large amount of saturated fatty acid resulted in a low content of unsaturated and cyclopropanoic fatty acids.

On the other hand, the fatty acid composition of the BL differed distinctly from that of the EL (Table 3). It consisted mainly of 3-hydroxy fatty acids (80\%) and of relatively short-chain fatty acids $(20 \%)$. Since the 3-hydroxy fatty acid content was $50 \%$ in the alkaline hydrolysate, 3-hydroxy fatty acids were presumed to be bound by amide and ester linkages. These data were highly reproducible when the organisms were cultured under standardized conditions.

Analysis of lipid A. The lipid A backbone of various bacteria is composed of $\beta$-glucosaminyl1,6-glucosamine units carrying two phosphate groups $(4,10)$. Hydroxy and amino groups of glucosamine disaccharide units are substituted by fatty acids (17). To examine strains ATCC 190 and ATCC 6627 for glucosamine, lipid A was separated from the lipopolysaccharide fraction 


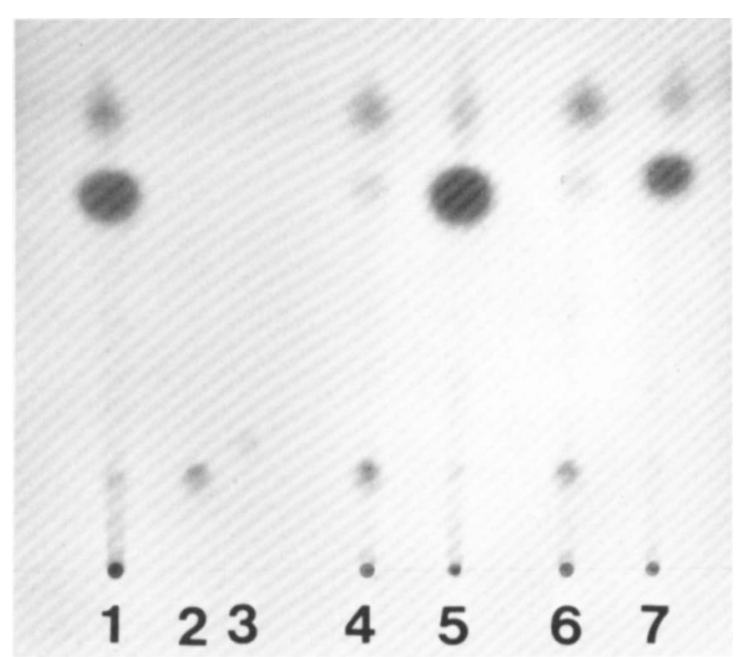

FIG. 3. Thin-layer chromatograms of fatty acid methyl esters from EL and BL. The plate was developed with the solvent system of petroleum ether-ether-acetic acid (80:30:1) and charred with 50\% sulfuric acid. Fatty acid methyl esters derived from: (1) EL of Escherichia coli K-12; (2) 3-hydroxy fatty acid; (3) 2-hydroxy fatty acid; (4) BL of ATCC 190; (5) EL of ATCC 190; (6) BL of ATCC 6627; and (7) EL of ATCC 6627.

TABLE 2. Fatty acid composition of extractable lipids from P. pertucinogena strains ATCC 190 and ATCC 6627

\begin{tabular}{|c|c|c|c|c|c|c|c|c|c|c|}
\hline \multirow[b]{3}{*}{ Fatty acid } & \multicolumn{10}{|c|}{ Fatty acid composition ${ }^{a}$ of extractable lipids from: } \\
\hline & \multicolumn{5}{|c|}{ ATCC 190} & \multicolumn{5}{|c|}{ ATCC 6627} \\
\hline & Total & $\begin{array}{c}\text { Phospha- } \\
\text { tidyle- } \\
\text { thano- } \\
\text { lamine }\end{array}$ & $\begin{array}{c}\text { Cardio- } \\
\text { lipin }\end{array}$ & $\begin{array}{l}\text { Phospha- } \\
\text { tidylgly- } \\
\text { cerol }\end{array}$ & $\begin{array}{l}\text { Lysocar- } \\
\text { diolipin }\end{array}$ & Total & $\begin{array}{c}\text { Phospha- } \\
\text { tidyle- } \\
\text { thano- } \\
\text { lamine }\end{array}$ & $\begin{array}{c}\text { Cardio- } \\
\text { lipin }\end{array}$ & $\begin{array}{l}\text { Phospha- } \\
\text { tidylgly- } \\
\text { cerol }\end{array}$ & $\begin{array}{l}\text { Lysocar- } \\
\text { diolipin }\end{array}$ \\
\hline $12: 0$ & $\mathrm{t}$ & $\mathrm{t}$ & $\mathrm{t}$ & $\mathrm{t}$ & $\mathrm{t}$ & $\mathbf{t}$ & $\mathrm{t}$ & $\mathrm{t}$ & $\mathrm{t}$ & $\mathrm{t}$ \\
\hline $13: 0$ & $\mathrm{t}$ & $t$ & $t$ & $t$ & $\mathrm{t}$ & $t$ & $\mathrm{t}$ & $t$ & $\mathrm{t}$ & $t$ \\
\hline $14: 0$ & 0.7 & 0.6 & 0.9 & 0.5 & 0.9 & 0.5 & 0.5 & 0.8 & 0.8 & 0.6 \\
\hline $14: 1$ & 0.8 & 0.6 & 1.4 & 2.8 & 8.0 & 2.0 & 2.5 & 1.4 & 5.5 & 11.7 \\
\hline $15: 0$ & 4.8 & 4.0 & 5.6 & 5.0 & 0.7 & 6.0 & 5.3 & 6.7 & 5.4 & 4.0 \\
\hline $15: 1$ & 0.4 & 0.4 & 0.6 & 0.5 & 0.7 & $t$ & $\mathrm{t}$ & $\mathrm{t}$ & $\mathrm{t}$ & $\mathrm{t}$ \\
\hline $2-\mathrm{OH} 14: 0$ & 0.5 & 0.5 & 0.3 & 0.1 & 0.1 & 0.5 & 0.5 & 0.3 & 0.1 & 0.3 \\
\hline $3-\mathrm{OH} 14: 0$ & $t$ & $\mathrm{t}$ & $\mathrm{t}$ & $\mathrm{t}$ & $\mathrm{t}$ & $\mathrm{t}$ & $\mathrm{t}$ & $t$ & $t$ & $\mathrm{t}$ \\
\hline $16: 0$ & 34.2 & 31.4 & 35.0 & 37.4 & 64.4 & 39.5 & 40.5 & 38.6 & 49.3 & 55.6 \\
\hline $16: 1$ & 2.0 & 1.3 & 2.3 & 1.1 & 3.3 & 2.4 & 2.7 & 2.5 & 2.8 & 2.6 \\
\hline $17: 0$ & 5.7 & 5.6 & 6.1 & 7.2 & 1.1 & 7.8 & 8.0 & 7.7 & 8.2 & 4.4 \\
\hline $17: 1$ & 9.5 & 12.1 & 6.5 & 11.7 & 4.7 & 1.2 & 1.6 & 1.1 & $t$ & $\mathrm{t}$ \\
\hline $17 \mathrm{CA}$ & 7.1 & 6.7 & 7.5 & 3.5 & 1.1 & 8.7 & 9.1 & 8.6 & 3.5 & 4.4 \\
\hline $18: 0$ & 6.5 & 6.1 & 6.5 & 7.5 & 7.1 & 4.5 & 4.3 & 4.8 & 6.6 & 5.6 \\
\hline $18: 1$ & 21.2 & 22.2 & 20.1 & 11.0 & 5.7 & 20.5 & 21.1 & 20.4 & 11.8 & 6.7 \\
\hline $19 \mathrm{CA}$ & 8.2 & 8.9 & 7.5 & 11.0 & 1.8 & 6.2 & 4.3 & 8.1 & 5.5 & 5.0 \\
\hline
\end{tabular}

${ }^{a}$ Expressed as percentage of total fatty acid methyl esters (on a weight basis). Abbreviations: CA, cyclopropane acid; $t$, trace.

prepared as described in Materials and Methods. After hydrolysis of lipid A, glucosamine was isolated by two-dimensional paper electrophoresis and chromatography as in the case with most Pseudomonas species but not with $P$. diminuta, as reported by Wilkinson et al. (21).
The fatty acids released from lipid A during hydrolysis were the same as those described previously for bound lipids.

Fatty acid composition of $B$. pertussis. As stated above, strains of $P$. pertucinogena had long been misidentified as phase IV $B$. pertussis 
TABLE 3. Fatty acid composition of bound lipids of P. pertucinogena strains ATCC 190 and ATCC 6627

\begin{tabular}{|c|c|c|}
\hline \multirow{2}{*}{ Fatty acid } & \multicolumn{2}{|c|}{$\begin{array}{l}\text { Fatty acid composition }{ }^{a} \text { of } \\
\text { bound lipids of: }\end{array}$} \\
\hline & ATCC 190 & ATCC 6627 \\
\hline $12: 0$ & 23.2 & 13.3 \\
\hline $3-\mathrm{OH} \mathrm{10:0}$ & 37.8 & 33.8 \\
\hline $3-\mathrm{OH} 12: 0$ & 27.0 & 36.6 \\
\hline $3-\mathrm{OH}$ iso $11: 0$ & 4.2 & 1.5 \\
\hline 3-OH 11:0 & 1.4 & 5.8 \\
\hline $3-\mathrm{OH} \mathrm{15:0}$ & 4.0 & 6.5 \\
\hline $13: 0$ & 1.7 & 2.5 \\
\hline
\end{tabular}

${ }^{a}$ Expressed as percentage of total fatty acids.

strains because they mimic features of and produce a bacteriocin active against phase I strains of $B$. pertussis. In this connection, we were interested in the lipid composition of $B$. pertussis, the details of which will be presented in a separate paper. However, for the convenience of comparing the fatty acid composition of $P$. pertucinogena with that of $B$. pertussis, a brief preliminary report on the latter will be included here.

In 1973, Thiele and Schwinn (18) worked on the EL of a single strain of $B$. pertussis. They reported that the major fatty acids of the individual phospholipids were hexadecanoic and hexadecenoic acids. From their data, the fatty acid composition of $B$. pertussis seemed to be different from that of $P$. pertucinogena. However, whereas they analyzed the EL of only one strain of $B$. pertussis, we studied many strains of phases I to IV in order to obtain a more nearly complete picture of the EL of this species.

According to our studies, the major fatty acids of the EL in the cells of strains of phases I to IV of $B$. pertussis were uniformly hexadecanoic acid $\left(\mathrm{C}_{16: 0}\right)$ and hexadecenoic acid $\left(\mathrm{C}_{16: 1}\right)$, which occupied about $90 \%$ of the total fatty acid. These two fatty acids were present in a ratio of about 1:1. On the other hand, the major fatty acids of the BL were, without phase difference, 3-hydroxytetradecanoic acid (3-OH $\mathrm{C}_{14: 0}$ ), tetradecanoic acid $\left(\mathrm{C}_{14: 0}\right)$, and 3-hydroxydecanoic acid (3$\left.\mathrm{OH} \mathrm{C}_{10: 0}\right) ; 3$-hydroxydodecanoic acid (3-OH C $\mathrm{C}_{12: 0}$ ) was also detected in some strains. Thus a difference between the fatty acid composition of $P$. pertucinogena and that of $B$. pertussis was evident.

\section{DISCUSSION}

It is generally accepted that in gram-negative bacteria the neutral solvent-extractable lipids are mainly the components of the cytoplasmic and outer membranes, and the bound lipids, which can be extracted only after hydrolysis, such as lipopolysaccharide and lipoprotein, are the components of the outer envelope.

In 1973, Thiele and Schwinn (18) reported on a comparison of the neutral solvent-extractable lipids and the fatty acids of a single strain of $B$. pertussis with those of other members of the family Brucellaceae. They found the major phospholipids of $B$. pertussis to be phosphatidylethanolamine, cardiolipin, and phosphatidylserine with ornithine-containing aminolipid; the major fatty acids of the phospholipids were palmitic and hexadecenoic acids. Our own studies on numerous phase I to IV strains of this same species indicated that $90 \%$ of the fatty acids of the EL consisted of hexadecanoic and hexadecenoic acids in the ratio of 1:1. We also studied in detail the fatty acid composition of the $\mathrm{BL}$ in this same species. The lipids of $P$. pertucinogena differed from those of $B$. pertussis, the former being simpler in phospholipid composition and more complex in fatty acid composition than the latter. The high cardiolipin content was characteristic of $P$. pertucinogena. From these comparative studies of lipid composition (6), it is quite reasonable to regard ATCC 190 and ATCC 6627 as pseudomonads and not as bordetellas.

The classification of bacteria on the basis of their lipid and fatty acid compositions is a rather recent development $(1,6,13,15)$. Detailed studies by Wilkinson et al. $(20,21)$ and by Moss et al. $(11,14)$ suggested the possibility of a chemotaxonomy of the pseudomonads on the basis of the lipid and fatty acid compositions of the cells. In fact, Moss and Dees (12) divided the genus Pseudomonas into eight groups on the basis of the cellular and extracellular fatty acid composition. For the effective and rapid identification of species, they recommended a combination of conventional and relatively simple gas-liquid chromatography tests for fatty acids. Yano et al. (23) divided the genus Pseudomonas into five groups by lipid and fatty acid analyses, and the resultant groups coincided with the nucleic acid homologies reported by Palleroni et al. (16). The classification proposed by Moss and Dees coincided substantially with that by Yano et al.

The fatty acid and lipid composition of $P$. pertucinogena was similar to that of other members of the genus Pseudomonas, especially to that of group III organisms of Moss and Dees, including $P$. stutzeri, $P$. pseudoalcaligenes, and $P$. mendocina (12). This observation coincided with our previous observation that $P$. pertucinogena is most similar to $P$. pseudoalcaligenes, among the species tested, with respect to deoxyribonucleic acid homology, the possession of a single polar flagellum, and the inability to utilize glucose as a sole carbon source (8). 


\section{ACKNOWLEDGMENTS}

We thank I. Yano (Osaka City University, Osaka) and Y. Akamatsu (National Institute of Health, Tokyo) for their useful advice and their supply of fatty acid standards. We thank I. Yano for his help in mass spectrometry. We are also grateful to K. Kanai (National Institute of Health, Tokyo) and G. Sakaguchi (Osaka Prefectural University, Osaka) for their assistance in preparing the manuscript.

\section{REPRINT REQUESTS}

Address reprint requests to: Dr. Yoko Kawai, Department of Bacteriology I, National Institute of Health, Shinagawa-ku, Tokyo 141, Japan.

\section{LTERATURE CITED}

1. Abel, K., H. de Schmertzing, and J. I. Petersen. 1963. Classification of microorganisms by analysis of chemical composition. J. Bacteriol. 85:1039-1044.

2. Bligh, E. G., and W. J. Dyer. 1959. A rapid method of total lipid extraction and purification. Can. J. Biochem. Physiol. 37:911-917.

3. Dawson, R. M. C. 1960 . A hydrolytic procedure for the identification and estimation of individual phospholipids in biological sample. Biochem. J. 75:45-53.

4. Hase, S., and E. T. Rietschel. 1976. Isolation and analysis of the lipid A backbone. Lipid A structure of lipopolysaccharide from various bacterial groups. Eur. J. Biochem. 63:101-107.

5. Jebb, W. H. H., and A. H. Tomlinson. 1955. The nutritional requirements of Haemophilus pertussis. J. Gen. Microbiol. 13:1-8.

6. Kates, M. 1964. Bacterial lipids. Adv. Lipid Res. 2:17-90.

7. Kawai, Y. 1974. Purification and characterization of pertucin produced by Pseudomonas pertucinogena. Antimicrob. Agents Chemother. 6:347-359.

8. Kawai, Y., and E. Yabuuchi. 1975. Pseudomonas pertucinogena sp. nov., an organism previously misidentified as Bordetella pertussis. Int. J. Syst. Bacteriol. 25:317-323.

9. Litkenhous, C., and P. V. Liu. 1967. Bacteriocin produced by Bordetella pertussis. J. Bacteriol. 93:1484-1488.

10. Lüderitz, O., C. Galanos, V. Lehman, M. Nurminan, E. T. Rietschel, G. Rosenfelder, M. Simon, and 0. Westphal. 1973. Lipid A: chemical structure and bio- logical activity. J. Infect. Dis. 128(Suppl.):S17-S29.

11. Moss, C. W., and S. B. Dees. 1975. Identification of microorganisms by gas chromatographic-mass spectrometric analysis of cellular fatty acids. J. Chromatogr. 112:595-604.

12. Moss, C. W., and S. B. Dees. 1976. Cellular fatty acids and metabolic products of Pseudomonas species obtained from clinical specimens. J. Clin. Microbiol. 4:492-502.

13. Moss, C. W., M. W. Lambert, and W. H. Merwin. 1974. Comparison of rapid methods for analysis of bacterial fatty acids. Appl. Microbiol. 28:80-85.

14. Moss, C. W., S. B. Samuels, and R. E. Weaver. 1972. Cellular fatty acid composition of selected Pseudomonas species. Appl. Microbiol. 24:596-598.

15. Oliver, J. D., and R. R. Colwell. 1973. Extractable lipids of gram-negative marine bacteria: fatty acid composition. Int. J. Syst. Bacteriol. 23:442-458.

16. Palleroni, N. J., R. Kunisawa, R. Contopoulou, and M. Doudoroff. 1973. Nucleic acid homologies in the genus Pseudomonas. Int. J. Syst. Bacteriol. 23:333-339.

17. Rietschel, E. T., H. Gottert, O. Lüderitz, and O. Westphal. 1972. Nature and linkage of the fatty acids present in the lipid A component of Salmonella lipopolysaccharides. Eur. J. Biochem. 28:166-173.

18. Thiele, O. W., and G. Schwinn. 1973. The free lipids of Brucella melitensis and Bordetella pertussis. Eur. J. Biochem. 34:333-344.

19. Westphal, O., and K. Jann. 1965. Bacterial lipopolysaaccharides. Extraction with phenol-water and further applications of the procedure. Methods Carbohydr. Chem. 5:83-91.

20. Wilkinson, S. G., and L. Galbraith. 1975. Studies of lipopolysaccharides from Pseudomonas aeruginosa. Eur. J. Biochem. 52:331-343.

21. Wilkinson, S. G., L. Galbraith, and G. A. Lightfoot. 1973. Cell walls, lipids, and lipopolysaccharides of Pseudomonas species. Eur. J. Biochem. 33:158-174.

22. Yano, I., Y. Ohno, M. Masui, K. Kato, E. Yabuuchi, and A. Ohyama. 1976. Occurrence of 2- and 3-hydroxy fatty acids in high concentrations in the extractable and bound lipids of Flavobacterium meningosepticum and Flavobacterium llb. Lipids 11:685-688.

23. Yano, I., E. Yabuuchi, M. Shimogawa, Y. Ohno, M. Nasui, and K. Kato. 1976. Lipids and fatty acids of Pseudomonas species and their application to chemotaxonomy. Proc. Jpn. Conf. Biochem. Lipid 18:51-54. 